\title{
OVARIAN CANCER INCIDENCE TREND IN THE NIŠAVA DISTRICT
}

Biljana Kocić1,2, Nataša Rančić1,2, Mirko Ilić' ${ }^{2}$ Ilija Kocić $^{1}$

\author{
${ }^{1}$ University of Niš, Faculty of Medicine, Niš, Serbia \\ ${ }^{2}$ Institut of Public Health, Department of Epidemiology, Niš, Serbia \\ Acta Medica Medianae 2021;60(1):13-18.
}

\section{Acknowledgment}

This study was supported by the Ministry of Education, Science and Technological Development of the Republic of Serbia (project number III 46013). 